\title{
Uwagi o (nie)przydatności konceptu homo sovieticus na przykładzie badań wśród białoruskich kołchoźników
}

\section{Abstract \\ Some Remarks about the (Un)usefulness of the Concept of Homo Sovieticus According to the Research on Belarusian Kolkhoz Villagers}

The author on the grounds of her ethnographic field research in kolkhoz villages in Belarus negatively verifies the established, orientalising concept of homo sovieticus as a possible tool of interpretation. She concentrates on the relation between the kolkhoz inhabitants and the authorities at both the local and the state level. She argues that in the kolkhozniks' worldview the authorities at both levels are a modern variant of a feudal pattern of the "good master". The concept of homo sovieticus has been constructed to grasp the psychological effects of long-term living under the rule of the authoritarian Soviet system: fearing the authorities and having a slave-like approach to them. The Belarusian villagers have rather functioned in a symbiosis with the authorities, based on a feudal principle of hierarchical complementarity. As the imaginary of the kolkhozniks reflects the archaic, sacral content of the more distant past, it seems more adequate to define them as homo (post)traditional or homo (post)feudalism.

Keywords: homo sovieticus, kolkhoz, field research, Belarusian studies

Po krytycznej analizie „legendarnego kompleksu homo sovieticus”, przeprowadzonej przez Michała Buchowskiego (Buchowski 2006, 2008) i Jana Kubika (Kubik 2012) ${ }^{1}$, nie można już nie patrzeć na ten tak chętnie esencjalizowany i zarazem

1 Przedmiotem krytyki zarówno Buchowskiego, jak i Kubika jest koncepcja homo sovieticus w postaci zaproponowanej przez P. Sztompkę (Sztompka 2000). Nawiązywał on do propozycji 
ideologizowany koncept jako na jeden ze sposobów społecznego tworzenia Innego, reprodukujący „podział na cywilizowanych «nas» i prymitywnych «onych»" (Buchowski 2008: 102); na stygmatyzującą etykietę będącą symptomem „praktyk orientalizujących" (Buchowski 2008: 107). Nie można też nie być świadomym, że pojęcie to nie zostało wywiedzione z badań empirycznych. Etnograficzna korekta socjologicznego opisu tego konceptu doprowadziła do wniosku, że nie istnieje homo sovieticus „reifikowany jako mniej lub bardziej koherentny syndrom kulturowy, odnoszony jako całość do całej kategorii czy klasy ludzi” (Kubik 2012: 257). Można jedynie mówić, jak stwierdził Kubik, o występowaniu niektórych jego elementów składowych w lokalnych wariantach wiedzy potocznej i scenariuszach kulturowych, przy czym scenariusze te mogą się znacznie różnić między sobą, a mogą też być takie, w których nie występuje żadna z jego cech. Wreszcie nie można też nie zdawać sobie sprawy $\mathrm{z}$ ahistoryzmu konceptu homo sovieticus. Pojmowany jako mentalna pozostałość po systemie sowieckim² ${ }^{2}$, abstrahuje on od ustaleń historyków, podzielających przekonanie, że mentalność, będąca fenomenem longue durée, zmienia się bardzo powoli (por. Kubik 2012: 250). Pojawiają się wprawdzie nowe, aktualne treści zbiorowych wyobrażeń, jednak funkcjonują one w tradycyjnej „mentalnej matrycy” (por. Malewska-Szałygin 2008: 209-210 i passim), w mających niejednokrotnie bardzo starą metrykę schematach wyobrażeniowych, strukturach semiotycznych i aksjologicznych.

Mimo zdezawuowania przez antropologów tego gabinetowego, skonstruowanego przez filozofów i socjologów konceptu, może warto poddać go jeszcze nieco innej próbie niż poprzednicy? Krytycznym narzędziem w ręku Kubika były lokalne etnografie dwóch polskich społeczności góralskich, silnie zintegrowanych wokół swoich wartości ${ }^{3}$. Nie odwoływał się on na przykład do badań nad postmigracyjnymi społecznościami wsi popegeerowskich; być może tam łatwiej dałoby się uchwycić jakąś konfigurację istotnych cech poszukiwanego syndromu? Może więc wyniki pracy terenowej we wsiach kołchozowych w byłej republice radzieckiej - jak w moim wypadku, w Białorusi - skłonią nas do innego spojrzenia na przydatność dla etnografa teoretycznych narzędzi wypracowanych przez twórców konceptu homo sovieticus? Może w tamtejszych kołchozach, będących projektami sowieckiej inżynierii społecznej, zamieszkanych przez społeczności o ujednoliconej strukturze, zależne ekonomicznie i administracyjnie od władzy, dadzą się uchwycić jakieś elementy tego syndromu mające moc wyjaśniającą? Może też, ba-

twórcy tego pojęcia, A. Zinowiewa (Zinowiew 1984, 1986), i jej późniejszego rozwinięcia przez J. Tischnera (Tischner 2005).

2 Jak pisał Tischner: „Ujmując rzecz najogólniej: homo sovieticus to zniewolony przez system komunistyczny klient komunizmu - żywił się towarami, jakie komunizm mu ofiarował. [...] Jest on jak niewolnik, który po wyzwoleniu z jednej niewoli czym prędzej szuka sobie drugiej. Homo sovieticus to postkomunistyczna forma «ucieczki od wolności», którą opisał kiedyś Erich Fromm" (Tischner 2005: 141).

3 Kubik skonfrontował koncept homo sovieticus z dwoma lokalnymi kontekstami kulturowymi: Podhala (na podstawie: Malewska-Szałygin 2008) i Śląska Cieszyńskiego (badania własne). 
dając scenariusze kulturowe obszaru poradzieckiego, należy się odwołać do opracowań tytułowego zagadnienia zaproponowanych przez wychodzących od propozycji twórcy konceptu, Aleksandra Zinowiewa, autorów rosyjskich, czego nie robili przywołani wyżej krytycy? Mam tu na myśli zapoczątkowane w roku 1989 przez socjologa Jurija Lewadę i prowadzone do dziś przez jego kontynuatorów badania nad typem człowieka ukształtowanym w ZSRR - tak zwanym prostym człowiekiem radzieckim (sowietskij prostoj czełowiek) ${ }^{4}$; są to zakrojone na masową skalę i cyklicznie powtarzane badania rosyjskiej opinii społecznej (Lewada 1993, 2000, i in.; por. też Dunaeva 2012).

Wyruszmy zatem do białoruskich kołchozów tropem homo sovieticus, koncentrując się na tym aspekcie syndromu, który dotyczy szeroko rozumianej relacji między człowiekiem i władzą. Analizując tę relację, jesteśmy w samym centrum interesującego nas zagadnienia - wszak według Zinowiewa typ homo sovieticus (homosos) wykształcił swoje cechy psychospołeczne w wyniku przystosowania się do warunków kontrolowanego przez totalitarną władzę komunistycznego/ socjalistycznego społeczeństwa (por. Zinowiew 1986: 1). W ujęciu Lewady prosty człowiek radziecki jest sterowany przez ciągły strach przed władzą i niewolniczy stosunek do niej. Przyświeca mu motto „Władza wie lepiej, co jest dla wszystkich dobre" (Dunaeva 2012: 69). Choć oczekuje opieki ze strony państwa, jednocześnie prowadzi z nim nieuczciwą grę za pomocą kłamstwa, kradzieży i oszustwa („kombinowania”). Jako „produkt” takiej władzy jest konformistą i zarazem człowiekiem nieufnym, cynicznym i przebiegłym: cechują go dwójmyślenie i demonstracyjna lojalność. Te i wiele innych cech wymienianych jako charakterystyczne dla syndromu składają się na wzór złamanego przez przemoc zakłamanego niewolnika.

Etnograficzne badania terenowe w Białorusi prowadziłam w latach 1993-2012, samodzielnie i w zespołach badawczych, w kilkudziesięciu wsiach kołchozowych ${ }^{5}$. Wywołane w ich trakcie źródła - etnograficzne rozmowy - ukazują wiedzę potoczną białoruskich kołchoźników w jej wielowątkowym bogactwie, ambiwa-

4 Projekt „Sowietskij czełowiek” (później „Sowietskij prostoj czełowiek”) został zapoczątkowany w 1989 r. przez J. Lewadę, dyrektora Wszechrosyjskiego Ośrodka Badania Opinii Społecznej (WICOM); od 2003 r. jest kontynuowany w prywatnym Analitycznym Centrum Jurija Lewady.

5 Etnograficzne badania terenowe (stacjonarne i rekonesansowe) prowadziłam w Białorusi przez dwie dekady (1993-2012). Objęły one ok. 70 wsi kołchozowych w zachodniej Białorusi (obw. grodzieński i brzeski) i ok. 40 we wschodniej (obw. homelski, mohylewski i witebski). Z reguły były to wsie oddalone od większych centrów, także od miast rejonowych. Pracowałam z grupami studentów, z białoruskimi kolegami etnografami, a także sama. Materialnym efektem badań jest korpus ok. 700 nagranych rozmów przede wszystkim z najstarszymi mieszkańcami wsi (nie był to wynik strategii badawczej, lecz struktury demograficznej białoruskich wsi). Mniej więcej połowa z nich była wyznania prawosławnego, połowa - katolickiego. Znaczna większość rozmówców ukończyła kilka klas szkoły podstawowej, choć zdarzali się zarówno analfabeci, jak i osoby z wykształceniem średnim i wyższym. Szczegółowo o metodzie, założeniach i przebiegu badań piszę w: Engelking 2012: 19-38. 
lencjach, sprzecznościach, archaiczności i aktualności. Rozmówcy - prawosławni i katolicy, kobiety i mężczyźni, wykształceni i niewykształceni - to w ogromnej większości przedstawiciele najstarszego i średniego pokolenia, którzy przeżyli traumę kolektywizacji i rozkułaczania lub znają ją z przekazu rodzinnego. Są to ludzie do dziś odczuwający osobiste skutki politycznych, administracyjnych i społecznych procesów sowietyzacji; po upadku Związku Radzieckiego ich sytuacja się nie zmieniła - nadal pozostają gospodarzami wywłaszczonymi ze swojej ziemi. W Białorusi, inaczej niż w sąsiadujących z nią Rosji, Ukrainie i Litwie, nie rozwiązano kołchozów. Choć po roku 2000 poddano je różnego typu przekształceniom własnościowym i prawno-administracyjnym, w świadomości i nomenklaturze mieszkańców są one nadal kołchozami. Na wschodzie kraju gospodarstwa kolektywne funkcjonują od przełomu lat 20. i 30. XX wieku, na zachodzie o 20 lat krócej. Zdążyło już więc dorosnąć kilka pokoleń ludzi urodzonych w kołchozach. Mogłoby się wydawać, że właśnie oni - poddani sterowanej z zewnątrz destrukcyjnej zmianie i eksperymentom inżynierii społecznej - powinni przejawiać cechy „typowych” homososów.

Powtarzane przez kołchoźników refrenowe zdanie „Nam przychodzi żyć na miejscu przy każdej własti [tj. władzy]" (G97Dyl.BS) ${ }^{6}$, oprócz tego, że wyraża naczelną wartość chłopskiego etosu, jaką jest życie, wraz z imperatywem troski o nie, zwraca uwagę na niezwykle istotny aspekt ich scenariusza kulturowego, pomijany $\mathrm{w}$ prowadzonych z perspektywy makro badaniach socjologów - czyli lokalność. Jak pokazał Jan Kubik, uogólniona perspektywa syndromu homo sovieticus lekceważy lokalne etnografie; również badania rosyjskiej opinii społecznej dotyczące "prostego człowieka radzieckiego" nie uwzględniają kontekstów lokalnych. Tymczasem białoruscy kołchoźnicy to przede wszystkim ludzie „tutejsi”, od pokoleń zakorzenieni w dobrze znajomej sieci relacji obejmującej ich wieś, kołchoz, parafię i gminę, w codzienności wyznaczanej konfiguracją silnych więzi rodzinno-rodowo-sąsiedzkich. Fundament tej charakterystycznej dla społeczeństw chłopskich tożsamości tworzą lokalne więzi społeczne, praca na ziemi i kategoria "swojego" (swoich ludzi, swojej własności, swojego otoczenia). Nie mają dla niej konstytutywnego znaczenia ponadlokalne, tworzone przez nowoczesny obieg piśmienny koncepty polityczne i ideologiczne (w tym narodowe), decydujące są natomiast odniesienia do sacrum i do przednowoczesnego porządku podziałów stanowych i dystynkcji religijnych. Swoje miejsce w świecie społecznym kołchoźnicy definiują w odniesieniu do znaczących innych, których wzory ukształtowała epoka feudalna - symbolicznego „pana” i „Żyda”; swoją kondycję ludzką określają przez odwołanie do dwóch wartości naczelnych: pracy na ziemi i wiary w Boga ${ }^{7}$.

6 Symbole w sygnaturach rozmów oznaczają: obwód, rok przeprowadzenia rozmowy, miejscowość, inicjały rozmówcy. W spisie rozmówców na końcu artykułu rozwijam zakodowane w sygnaturach informacje o ich wieku i wyznaniu oraz przypisaniu administracyjnym ich miejsca zamieszkania.

Antropologicznej analizie zbiorowej tożsamości białoruskich kołchoźników jest poświęcona moja książka: Engelking 2012. 
Ich sakralne paradygmaty postrzegania świata, kontynuujące modele mentalne właściwe najniższej warstwie społeczeństwa feudalnego - pańszczyźnianym chłopom, skłaniają do tego, by widzieć w nich nie tyle potwierdzenie, ile przeciwieństwo tej cechy interesującego nas syndromu, którą Tischner zdefiniował jako podstawową: „Kim był ów homo sovieticus? Przede wszystkim była to istota «jednowymiarowa», dla której nie istniał wymiar wertykalny egzystencji ludzkiej, lecz wszystko, co najważniejsze, mieściło się na tej ziemi. Można powiedzieć: istota «sterryzowana» [od łac. terra - ziemia]. (...) Homo sovieticus, zgodnie z naukami klasyków, nie mógł mieć «duszy»" (Tischner 2005: 187). Białoruscy kołchoźnicy, stanowiący także w radzieckim społeczeństwie (niezależnie od oficjalnej ideologii i fasady „demokracji kołchozowej”) warstwę najniższą, ubezwłasnowolnioną i pogardzaną, warstwę „prostych, czarnoroboczych, ostatnich ludzi”, jakich „za człowieka nawet nie liczą [tj. nie uważają]” (G98Bl.JWM), zachowali w warunkach tego systemu osobistą godność i etos pracy. $\mathrm{Na}$ wsi białoruskiej „pracą masowopolityczną" obejmowano uczące się dzieci i młodzież, które w ogromnej większości zasilały później szeregi ludności miast; pozostający w kołchozach ich z reguły słabo wykształceni (moimi rozmówcami niejednokrotnie były osoby niepiśmienne) rodzice i dziadkowie nie stanowili dla władzy radzieckiej wartego zachodu obiektu obróbki ideologicznej. Mieli być przede wszystkim posłusznymi i niekłopotliwymi robotnikami rolnymi, wykonującymi najcięższą fizyczną pracę.

Sposób, w jaki białoruscy kołchoźnicy konceptualizują domenę władzy i swoje relacje z nią, uderzająco często odwołuje się do archaicznych treści kultury. Przypomina stosunek do zjawisk przyrody. Władza po prostu jest - przychodzi z zewnątrz i rządzi się własnymi prawami, w które „prosty roboczy człowiek” (tak brzmi autodefinicja kołchoźnika) nie wnika i których nie kwestionuje. Z reguły odpowiedź na zadawane przez etnografa pytanie o przyczynę zachodzących zmian politycznych i społecznych brzmi: „No, właść [tj. władza] taka przyszła” (G97Mac.WR). To władza "robi” lub likwiduje poszczególne państwa, zmienia urzędowe języki, „zamyka”, a potem „otwiera” albo „daje” wiarę, odbiera gospodarzom ziemię i zapędza ich do kołchozu, a potem pozwala wyjść z kołchozu i swoją dawną ziemię wydzierżawić lub niewielki jej skrawek kupić. Niezależnie od tego, czy człowiek godzi się z takim stanem rzeczy, czy też się przeciw niemu buntuje, przyjmuje, że nie ma nań żadnego wpływu. Dlatego tak łatwo usłyszeć tu fatalistyczny refren człowieka pogodzonego $\mathrm{z}$ istniejącym porządkiem: „A coż tu zrobić? Tak musi być".

„Tradycyjna koncepcja państwa - pisał w latach 30. Józef Obrębski - (...) jest typową koncepcją feudalną. [Zgodnie z nią] władza i państwo to (...) elementy naturalnego porządku świata. (...). Mogły się zmieniać państwa i rządy; podział

\footnotetext{
8 Obszernie na ten temat piszę w: Engelking 2012.
} 
na lud rządzony i rząd rządzący był wieczny i jako porządek naturalny winien trwać wiecznie" (Obrębski 2007b: 307-308) ${ }^{9}$. Wydaje się, że realna władza innego szczebla niż lokalny - państwowa - znajduje się poza horyzontem kołchoźników. W tej najwyższej, oddalonej władzy liczy się dla nich tylko zmityzowana postać głównego przywódcy, dawniej radzieckiego, dziś białoruskiego; etnograf prędko się orientuje, że jest on postrzegany zgodnie z tradycyjnym wzorem „dobrego cara” („cara mużyków”, tj. chłopów) (por. Obrębski 2007a: 116-119; Engelking 2012: 117-120, 180-185; Malewska-Szałygin 2008: 59-115). Do zadań tego dobroczyńcy i opiekuna należy zapewnienie ludziom środków do życia (w postaci pensji i emerytur) oraz osobistego bezpieczeństwa, zgodnie z oczekiwaniami, które formułują następująco: „Nam by kusok chleba na stale i cicho na świecie było biez wajny, szto nam bulej nada?” [Nam, żeby kawałek chleba na stole i żeby na świecie było cicho, bez wojny - co nam więcej potrzeba?] (H03Jur.PP). Dlatego, jeżeli tylko ów władca troszczy się o lud, czyli realizuje patriarchalny archetyp, pełni wdzięczności mówią: „U nas Łukaszenka ad Boha. Kab u nas nie stał Łukaszenka, myb użo chleb z wodoju jeli" [Łukaszenkę dał nam Bóg. Gdyby nie było u nas Łukaszenki, to już byśmy żyli o chlebie i wodzie] (B06Kos.AL).

Zgodnie z dawną feudalną i do dziś żywotną rosyjską tradycją quasi-religijnego kultu władzy postać najwyższego władcy jest sakralizowana (por. Broda 2007). Sacrum jednak, jak uczy jego fenomenologia, ma oblicze ambiwalentne. Negatywna, wręcz demoniczna, strona władcy ujawnia się wtedy, gdy nie wypełnia on swoich patriarchalnych powinności, a więc gdy traci atrybuty ojca-opiekuna, wtedy, gdy przestaje troszczyć się o zwykłych ludzi i stać na straży hierarchicznego porządku społeczeństwa. Taki negatywny aspekt ma na przykład postać Gorbaczowa, przez wielu nienawidzonego za to, że „zrobił demokrację”: „Pry sowieckuj właści uxsio było (...): żyli ludzi - wo! A ciapieraka bardak zrobili. (...) Harbaczou dziemokraciju zrobiư . Jaho nado podwiesić na wiaroukku, dy powiesić, kab ludzi dziwilisia. (...) Swołacz" [Przy władzy radzieckiej było wszystko, ludzie żyli, oho! A teraz burdel tu zrobili. Gorbaczow demokrację zrobił. Jego należy powiesić na sznurze, powiesić, żeby ludzie widzieli. Swołocz!] (H03Aksndr.JD).

Kołchoźnik, zajmujący dziś tę samą podległą pozycję społeczną co dawniej chłop pańszczyźniany, parobek i robotnik rolny, nie postrzega siebie jako siły sprawczej, która mogłaby generować zmiany w domenie władzy.

- Pa czyjej winie hety biesparadak? [Z czyjej winy ten bałagan?]

- $\mathrm{Nu}$, jaż nie znaju, chto winawaty. (...) Ja dumaju tak nada, takaja płanieta [No, nie wiem, kto tu winny. (...) Myślę, że tak było trzeba, że tak to jest na ziemi]” (H03Aleks.HAK).

9 O tradycyjnej chłopskiej postawie wobec państwa i najwyższej władzy pisali przed II wojną światową m.in. F. Znaniecki (por. Thomas, Znaniecki 1976: 132-134, 220) i J. Obrębski (por. Obrębski 2007b: 287-288, 307-309). O chłopskiej, dawnej i współczesnej, wizji państwa jako wytworze procesów mityzacji, wartościowanym ambiwalentnie i niepodatnym na zmiany, oraz patriarchalnej, sakralizowanej wizji władzy zob. Malewska-Szałygin 2008: 59-98. 
„Cały ten system, to połączenie bezosobowej władzy i na wpół religijnej hierarchii, umożliwia oczywiście wyjaśnienie wszystkiego, ale absolutnie wyklucza ideę politycznej działalności. Chłop może jedynie biernie akceptować wydarzenia i radować się albo smucić” (Thomas, Znaniecki 1976: 133). Dlatego, zgodnie z tym tradycyjnym scenariuszem, przemiana bardaku i biesparadku w porządek może przyjść jedynie z góry - wypłynąć od władzy:

- Nu, a jak zrabić tak, kab było lepsz żyć? [No, a jak to zrobić, żeby żyło się lepiej?]

- [rozmówczyni 1:] Jak? Pastawić z taho świetu Stalina. [Jak? Przywołać z tamtego świata Stalina.]

- [rozmówczyni 2:] Kab byụ paradak [Żeby był porządek] (H03Aksndr.JD).

Postacie Lenina i, zwłaszcza, Stalina, ucieleśniające ideał porządku i dyscypliny, odzwierciedlają kołchoźniczą koncepcję silnej i sprawiedliwej władzy. Władzy, która stoi na straży porządku także w lokalnym kosmosie. Na ten sam mechanizm wskazała Caroline Humphrey, brytyjska badaczka kołchozów w radzieckiej i poradzieckiej Rosji (co znamienne, nieodwołująca się w swoich pracach do konceptu homo sovieticus): „Dostarczycielem (...) ładu ma być płynąca z góry władza. Jeśli lokalne instytucje ładu nie zapewniają, ludzie oczekują, iż zapewnią go wyższe organy polityczne, kumulujące się w symbolicznej reifikacji najwyższej władzy" (Humphrey 2010: 65).

Jednym z „dostarczających ładu” zadań najwyższego władcy jest kontrolowanie podległych mu funkcjonariuszy niższego szczebla. Kołchoźniczy obraz władzy znów konsekwentnie wpisuje się tu w feudalną koncepcję państwa, której „emocjonalną barwą (...) jest zaufanie do władzy, wyposażonej w atrybuty niemalże wszechmocności i uważanej za życzliwą dla ludu, choć nie zawsze dobrze poinformowaną" (Obrębski 2007b: 288). Dlatego niezadowolenie z sytuacji w kraju rzadko kierowane jest pod adresem prezydenta; dla kołchoźników jest oczywiste, że wszystkiemu są winni jego urzędnicy - rząd oraz władze średniego i niższego szczebla, zwane zbiorowo naczalstwem ${ }^{10}$. W negatywny obraz naczalstwa, które „nie daje ludziom żyć” i którego głównym zajęciem jest nieznająca żadnych hamulców kradzież - „U prawicielstwie - biary szto choczasz dy niasi. Jany nia kraduć, a biaruć" [W rządzie - bierz, co chcesz, i nieś do siebie. Oni nie kradną, ale biorą] (H03Mauc.MB) - wpisuje się też oszukiwanie przez tę grupę „dobrego cara”. „Tam u Minsku siadziać zładziuhi (...), jon za imi uxsiemi nie ư⿱⺈⿵⺆⿻二丨 kaszenka nie znaje, chto tam szto robić" [Tam w Mińsku siedzą złodzieje, on ich wszystkich nie upilnuje. Łukaszenka nie wie, kto tam co robi] (H03Mauc.HJ).

${ }^{10}$ Ogólnie rozumiane naczalstwo to wzór kontynuujący dawne koncepty pańskich sług i podpanków, odnoszący się do władzy niższego szczebla, zależnej od wyalienowanego od niej „dobrego pana” czy „dobrego cara”. „Chłopem rządził i poganiał [go] nie pan, ale wójt i ekonom pański - pański sługa i pański batoh. To pańskie sługi, pańscy hajduki i chapuny byli bezpośrednim źródłem razów, krzywd, prześladowań i ucisku - nie pan. Z nimi też, a nie z wielkim «prawdziwym» panem, wiązały się kompleksy uczuciowe strachu, nienawiści i upokorzenia” (Obrębski 2007a: 111-112). 
Kiedy analizuje się wypowiedzi kołchoźników mówiące o „dobrym” najwyższym władcy i przeciwstawianym mu "złym” naczalstwie, nieodmiennie charakteryzowanym utartą frazą „co chcą, to robią", można dostrzec, że wpisują się one w kontekst innych znaczących opozycji. Rozmówcy przeciwstawiają "porządek” i „dyscyplinę" (asocjowane z pozytywnie waloryzowanymi srogimi karami) pojęciom takim, jak „złodziejstwo” (łączone w jeden szereg z „pijaństwem”), biesparadak [nieporządek], „razwalucha” [rozwalenie, rozpad], „bardak”/„burdel”. Pozytywny biegun tej opozycji to atrybuty „dobrego cara”, negatywny - „robiącego, co chce", czyli dbającego wyłącznie o własne interesy, naczalstwa. To właśnie ta grupa - nie zaś opiekuńczy i dobrze gospodarzący, choć niedoinformowany „car” - ponosi odpowiedzialność za to, że w niektórych kołchozach „nic nie zostało” i „niczego nie ma”. To właśnie oni napychają sobie kieszenie kosztem prostych kołchoźników: „Wsiu żyźń tak niesprawiedliwo robicca. Wot za szczo wony i wybiwajucca w peredowyje. Za czyj szczot? Za ludskij trud. Da nabiwajut sobie karmany, naczalstwo. Wono takeje i je, wiezdie takeje" [Całe życie tak niesprawiedliwie się dzieje. To dlatego oni zdobywają kierownictwo. Czyim kosztem? Ludzkiej pracy. I nabija sobie kieszenie władza. Tak to jest, i wszędzie tak] (B99Dreb.EJ).

Jednakże, podobnie jak wizerunek najwyższej władzy i zgodnie z naturą mitu, również kołchoźniczy obraz naczalstwa ma cechy ambiwalentne: „Ryba hnije z haławy. Kali brać naczalnika, pradsiedaciela rajispałkoma, to kali jon tupoj, to usie kałchozy buduć zabityja. Jesli jon z haławoju, pradpryimczywy, to budzie usio narmalna" [Ryba gnije od głowy. Weź naczelnika, przewodniczącego komitetu powiatowego - jeśli jest tępy, to wszystkie kołchozy będą zacofane. A jeśli z głową, przedsiębiorczy, to wszystko będzie normalnie] (H03Rom.JP). Naczalnik z głową, przedsiębiorczy, dzięki któremu „wszystko jest normalnie”, czyli panuje porządek - to dobry gospodarz. To ktoś, kto utrzymuje w swoim gospodarstwie-państwie, gospodarstwie-rejonie [tj. powiecie], gospodarstwie-kołchozie, tak samo jak kiedyś pan na folwarku, porządek i dyscyplinę, kontrolując pracę i motywując do niej podwładnych. Wiadomo bowiem, że: „Dzie dziscyplina, da dzie rukowodziciel, to żywuć łuczsze. A dzie niet dziscypliny, dy choziaina - kałchozi - dyk tam i chuże" [Gdzie dyscyplina i gdzie kierownik, tam żyją lepiej. A gdzie nie ma dyscypliny i gospodarza w kołchozie - tam gorzej] (H03Hlin.PK).

Kołchoźniczy obraz przewodniczącego kołchozu - predsiedaciela (szerzej por. Engelking 2012: 163-174) - jest bardzo odległy od potocznego stereotypu niekompetentnego, przekupnego i amoralnego sowieckiego funkcjonariusza, jak również od konceptu „człowieka przebiegłego” (czieławiek łukawyj), następująco skomentowanego przez Lewadę: „Cały mechanizm systemu sowieckiego formował zarówno "przebiegłych niewolników» (...), jak i nie mniej "przebiegłych panów». Jedni i drudzy oszukiwali siebie nawzajem i kłamali sami przed sobą" (Lewada 2000: 17) ${ }^{11}$. Obraz predsiedaciela wpisuje się w mityczny, ambiwalentny

11 O praktykowanym przez kołchoźników „kombinowaniu” jako strategii wpisanej w system wartości, kluczowych dla trwania wspólnoty, piszę w: Engelking 2012: 131-156. 
wzór dobrego/złego pana i ma czytelne konotacje z archaicznymi treściami kultury chłopskiej. W gospodarstwach kolektywnych bowiem, które repetują model dawnego folwarku/majątku, robotnicy rolni-kołchoźnicy nie są nikim innym niż poddanymi tego współczesnego „pana”. Z punktu widzenia rozmówców kołchozowa wspólnota jest konstytuowana przez opozycyjną parę: predsiedaciela, który rządzi, i kołchoźników, którzy „robią”"12; para ta funkcjonuje w symbiozie na zasadzie „hierarchicznej komplementarności”'13. Można powiedzieć za Humphrey, że w tej relacji „przywódca nie "wdziera się», ale jest tak samo zintegrowany jak pozostali członkowie społeczności" (Humphrey 2010: 224).

Patriarchalny wizerunek dobrego predsiedaciela-opiekuna, który troszczy się o ziemię, o zwierzęta i o ludzi, sprawiedliwie ich wynagradza i okazuje im szacunek, do złudzenia przypominający wzór osobowy dawnego, przedrewolucyjnego i przedwojennego "dobrego pana”, stale obecnego w przekazie tradycji, nosi wszelkie cechy wzoru dobrego gospodarza. Rozmówcy, mówiąc o nim, często nie używają nawet słowa predsiedaciel, ale haspadar, chaziain, arhanizatar [tj. gospodarz, organizator], a stereotypowy epitet predsiedaciela - dobry - w większości rozmów o nim pada z ich ust spontanicznie. Domena kołchozu jest tu reifikowana jako gospodarstwo $\mathrm{z}$ gospodarzem-predsiedacielem na czele (por. Humphrey 2010: 63-65): „Tam, dzie charoszy chaziain, trudalubiwy, (...) znaczyć, ciapier tam je kałchoz. (...) A ot, niet chaziaina - i niet niczaho" [Tam, gdzie dobry, pracowity gospodarz, znaczy się - tam jest kołchoz. A ot, nie ma gospodarza - nie ma niczego] (H03Mauc.MB).

Silne zakorzenienie wzoru dobrego gospodarza w obrazie kołchozu, stereotypowo uważanego wręcz za synonim niegospodarności, może zaskakiwać chyba tylko gabinetowych uczonych, dających się uwodzić apriorycznym kategoriom. Test terenu wykazuje bowiem, że relacje rzeczywistych, a nie wyobrażonych, kołchoźników (którzy, choć formalnie pozbawieni statusu gospodarzy, nie przestali myśleć w gospodarskich kategoriach) z władzą - państwową i lokalną - kształtują się według scenariuszy kulturowych pochodzących sprzed epoki sowieckiej. Jednym z takich scenariuszy jest źródłowa metafora gospodarstwa (Malewska-Szałygin 2008: 64-67 i passim). W Białorusi odnajdujemy tę metaforę w co najmniej dwóch domenach: wyobrażeniach o państwie i wyobrażeniach o kołchozie ${ }^{14}$.

12 Na temat konstytuującej przeciwstawienie chłopa i pana opozycji praca-niepraca por. Engelking 2012: 191-436; por. też Malewska-Szałygin 2008: 104-107; 132-144, gdzie autorka analizuje analogiczną koncepcję w Nowotarskiem.

13 „Przedwspółczesne społeczeństwa europejskie opierały się na zasadzie, którą można określić mianem «hierarchicznej komplementarności». (...) Społeczności te były komplementarne, ponieważ różne stany potrzebowały siebie nawzajem, i tak były pojmowane; ale zarazem były też hierarchiczne, ponieważ nikt nie udawał, że ta wzajemna potrzeba czyniła stany równymi” (Taylor 1995: 18-19).

14 Warto przypomnieć, że ros. skrótowiec kołchoz pochodzi od wyrażenia kollektiwnoje choziajstwo (białor. kałhas od kalektyunaja haspadarka), co znaczy "gospodarstwo kolektywne”; koncept gospodarstwa jest więc wpisany w samą nazwę tej instytucji. Na temat nieprzypadkowości używanych oficjalnie terminów choziain i choziajstwo por. Humphrey 2010: 63-64. 
W obu spotykamy wzór dobrego gospodarza: w kołchozie reprezentują go dobrzy predsiedaciele, w państwie - kolejni przywódcy ZSRR i prezydent Łukaszenka. Obraz i jednych, i drugich to współczesna mutacja archaicznego, sakralnego wzoru władcy.

System kołchozowy w Związku Radzieckim narzucił wsi swoistą refeudalizację $^{15}$, co spowodowało „zamrożenie” zarówno przednowoczesnych wzorów instytucjonalnych (folwark), jak i modelu chłopskiej tożsamości, opartego na przednowoczesnych matrycach mentalnych. Znajdujący się na samym dole hierarchii społecznej kołchoźnicy czują się ludźmi poddanymi patriarchalno-autorytarnej władzy wszystkich szczebli. Poddaństwo to przyjmują jako stan naturalny i współuczestniczą w nim, nieustannie aktualizując kształtującą relacje między ludźmi a władzą fundamentalną opozycję pan - poddany ${ }^{16}$. Opiera się ona na należącym do kulturowych powszechników „bezwarunkowym obowiązku godnego odwzajemniania", jak ujął to Marcel Mauss (Mauss 1973: 270), obowiązku postrzeganego w kategoriach wymiany darów, symbolizowanej przez zasadę do ut des (daję, abyś dał $)^{17}$. Z tej uniwersalnej kulturowej reguły - zasady sprawiedliwości, stanowiącej jeden z filarów chłopskiej wizji świata - wypływa zarówno powszechna tęsknota za porządkiem i dyscypliną, jak i zobowiązanie do wzajemnej lojalności między człowiekiem a władzą (por. Obrębski 2007b: 308). I poddany, i stojąca nad nim władza podlegają uniwersalnym regułom sprawiedliwości, których panem i egzekutorem ma być sam Bóg. Legitymizowana przez mit biblijny zasada sprawiedliwości, przez pryzmat której rozmówcy postrzegają swoje relacje z władzą wszystkich szczebli, nadaje spójność i moralny sens ich obrazowi społecznego ładu. Jest to wizja przednowoczesna, zasadniczo odmienna od charakteryzującej syndrom homo sovieticus koncepcji człowieka, który nie ufa władzy i boi się jej, i jednocześnie rozgrywa z nią gry, w których obie strony są przebiegłymi, oszukującymi się nawzajem uczestnikami.

Badając wizję świata społecznego i społeczne samopoczucie kołchoźników przez pryzmat ich wiedzy potocznej, konstatujemy, że choć uważają się za poddanych i pogardzanych, nie ma do nich zastosowania charakterystyczna dla tego syndromu metafora „przebiegłego niewolnika”. Feudalna, nie niewolnicza, postawa poddania wobec władzy nie wyklucza bowiem podmiotowości, godności i sprawczości. Te nieobecne w koncepcie homo sovieticus czy prostego człowieka

15 O żywotności idiomu feudalizmu i procesach transformacji socjalizmu w feudalizm („swego rodzaju powrocie do przeszłości”) we współczesnej Rosji pisze m.in. Humphrey (powołując się na K. Verdery i innych badaczy), por. Humphrey 2010: passim.

16 Opozycja ta wyraża się między innymi w symptomatycznych metaforach; jedną z nich jest notowana przeze mnie na Białorusi i przez Humphrey w Rosji metafora pańszczyzny (por. Engelking 2012: passim, Humphrey 2010: 25).

17 O systemie radzieckich przedsiębiorstw jako „posiadłości feudalnych”, opartych na wymianie między pracownikami a kadrą kierowniczą, por. Humphrey 2010: 59-60. 
radzieckiego cechy są źródłem i warunkiem rozbudowanych i skutecznych codziennych strategii adaptacyjnych wypracowanych przez pozbawionych własnych gospodarstw białoruskich chłopów. Jan Kubik, przeciwstawiając się stygmatyzowaniu ludzi etykietą homo sovieticus, łączonemu z przypisywaniem im „niekompetencji cywilizacyjnej” (Kubik 2012: 251 i passim), podkreślał wagę zdolności jednostki do aktywności i twórczej odpowiedzi na zachodzące zmiany ekonomiczne, polityczne i społeczne (Kubik 2012: 256 i passim). Ludzie są obdarzeni podmiotowością i dostosowują swoje strategie działania do sytuacji, używając znanych sobie wzorów kulturowych ${ }^{18}$. Moje badania nad białoruskimi kołchoźnikami - podobnie jak badania Tomasza Rakowskiego nad mieszkańcami obszarów potransformacyjnego bezrobocia w Polsce (Rakowski 2009) - w pełni potwierdzają to stanowisko.

Kołchoźnicy, jakkolwiek zaskakująco by to w pierwszej chwili brzmiało, są bowiem przede wszystkim gospodarzami (szerzej, por. Engelking 2012: passim). Ich działki przyzagrodowe - kilkudziesięcioarowe resztówki dawnych gospodarstw, pełniące funkcję "swojej” ziemi - stanowią arenę codziennych, wytrwałych strategii zapobiegliwości i przetrwania (por. Rakowski 2009: 286-290), co pozwala na znaczny stopień samowystarczalności w skromnych ramach wiejskiej gospodarki quasi-naturalnej. Gospodarska kategoria swojego nie tylko nie zniknęła z otoczenia społecznego wywłaszczonych kołchoźników, lecz nadal ogniskuje ich codzienne zajęcia i troski, dostarczając niezbędnego do życia poczucia sprawczości i godności. Godności, która wyrasta z silnego związku z ziemią ${ }^{19}$ i wysokiego wartościowania pracy rolnika. Te i inne normy i wartości etosu chłopskiego ogniskują się tu we wzorze dobrego gospodarza - społecznym ideale zarówno dawnych chłopów, jak i dzisiejszych kołchoźników. Trudno zaprzeczyć, że gospodarz i homo sovieticus - rozpoznawany „po szczególnym typie nieodpowiedzialności, która nie była prostym brakiem odpowiedzialności, lecz (...) nieodpowiedzialnością z pretensjami” (Tischner 2005: 189) - to kategorie wzajemnie się wykluczające.

Pokusa odwoływania się do konceptu homo sovieticus w opisach rzeczywistości poradzieckiej nasuwa się łatwo, zwłaszcza wobec jego rozpowszechnienia w myśleniu potocznym i ujęciach publicystycznych, nie tylko polskich. Oczekiwanie, że koncept ten okaże się adekwatnym narzędziem analitycznym w badaniach wsi kołchozowej, prędko weryfikują jednak zarówno dostarczająca bardzo złożonych

18 „Ludzie, którzy doświadczają sterowanej z zewnątrz zmiany społecznej, ani nie muszą koniecznie przyjmować postaw obronnych, ani nie są niekompetentni; często podejmują działania ofensywne. Zwykle wypływają one $\mathbf{z}$ wnętrza tworzonego kulturowo świata społecznego, najczęściej lokalnego lub regionalnego" (Kubik 2012: 272; podkreślenie autora). Kubik zaznacza, że centralną kategorią w analizach postsocjalizmu powinno być przystosowanie (adjustment).

19 Podobny fenomen odnotowała Humphrey w kołchozach w Buriacji, gdzie stabilne i lojalne wspólnoty kołchozowe są, jej zdaniem, efektem silnych więzi z ziemią (Humphrey 2010: 51). 
informacji praca etnograficzna w terenie, jak i późniejszy namysł w gabinecie, który musi być stymulowany przez antropologiczny obowiązek nieufności wobec kategorii apriorycznych i wielkich kwantyfikatorów. Moje doświadczenie terenowe potwierdza, że „domniemany syndrom homo sovieticus” (Kubik 2012: 272), jak również uogólniona koncepcja „prostego człowieka radzieckiego” nie znajdują zastosowania $\mathrm{w}$ antropologicznych badaniach nad mentalnością i scenariuszami kulturowymi białoruskich kołchoźników. Oba te filozoficzno-socjologiczno-politologiczne koncepty, których korzenie sięgają okresu walki ideologicznej między blokiem wschodnim i zachodnim, zostały ukute dla opisu zachowań człowieka zniewolonego i ubezwłasnowolnionego przez system totalnej opresji - zachowań obserwowanych zresztą w każdym systemie totalitarnym, nie tylko sowieckim. Odnoszą się do innego rodzaju osobowości społecznej niż ukształtowana w kulturze

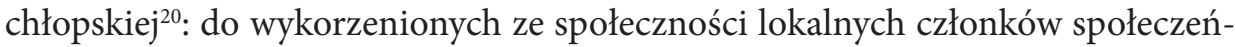
stwa masowego, w którym system tradycyjnych wartości podlega dezintegracji. Zinowiew napisał o homososie, że ,jest on istotą przede wszystkim ideologiczną" (Zinowiew 1986: 3); wydaje się, że białoruski chłop, w swoim współczesnym kołchozowym wcieleniu, stawia opór nowoczesnym ideologizacjom, pozostając istotą przede wszystkim religijną (szerzej, por. Engelking 2012: 583-757). Koncept homo sovieticus / prostego człowieka radzieckiego nie jest adekwatnym narzędziem do opisu i wyjaśnienia kontynuacji i mutacji kategorii kultury chłopskiej w ich współczesnym postfeudalnym wariancie białoruskim.

Jeśli przyjąć, że dzisiaj można rozumieć syndrom homo sovieticus (bądź jego poszczególne elementy) jako teoretyczny konstrukt usiłujący uchwycić mentalne skutki opresyjnego systemu sowieckiego, to wyniki badań wśród mieszkańców wsi białoruskiej każą przede wszystkim sięgać głębiej w historię i pytać o żywe w ich mentalności ślady epok znacznie odleglejszych. Z perspektywy longue durée ich paradygmaty postrzegania świata mają bowiem - podobnie jak w przypadku społeczności lokalnych badanych w Polsce - „raczej charakter posttradycyjny (...) niż postkomunistyczny czy postsocjalistyczny (...) - zakorzeniony $\mathrm{w}$ tradycji, a przy tym przekształcony" (Malewska-Szałygin 2008: 206-207). O ile więc w ogóle odnosić do białoruskich kołchoźników jakiekolwiek koncepty-etykiety (ze świadomością, że ich funkcja jest nie tyle wyjaśniająca, ile wskazująca obszary hipotez wymagających weryfikacji badawczej), bardziej adekwatne wydawałyby się homo (post)traditionalis bądź homo (post)feudalis. Stosowane ze świadomością ich ograniczeń, jakie ma każdy model, i konfrontowane ze zmieniającą się w czasie i zróżnicowaną regionalnie rzeczywistością białoruskiej wsi, mogłyby stanowić punkt wyjścia do niepodjętych dotąd, o ile mi wiadomo, badań nad młodym

20 Por.: „Cechy homososa najwyższy swój stopień dojrzałości osiągnęły w ludziach radzieckich o stosunkowo wysokim poziomie kultury i wykształcenia, a także w środowisku najbardziej aktywnej społecznie części ludności, szczególnie zaś - w sferze zarządzania, nauki, propagandy, kultury, szkolnictwa. Ta z kolei część wysoko rozwiniętych homososów wywiera wpływ na pozostałą część ludności, a także i na zewnątrz" (Zinowiew 1986: 3). 
pokoleniem kołchoźników. W takich badaniach należałoby też ponownie zapytać o elementy syndromu homo sovieticus.

\section{Bibliografia}

Broda M.

2007 Archaiczne uwikłania i mentalno-społeczne korelaty sakralizacji władzy w Rosji, w: A. Andrusiewicz (red.), Polska i jej wschodni sąsiedzi, Studia Wschodnioznawcze, t. 8, Rzeszów, s. 250-257.

Buchowski M.

2006 The Specter of Orientalism in Europe: From Exotic Other to Stigmatized Brother, „Anthropological Quarterly”, vol. 79, no. 3, p. 463-482.

2008 Widmo orientalizmu w Europie. Od egzotycznego Innego do napiętnowanego swojego, „Recykling Idei”, nr 10, s. 98-107.

Dunaeva V.

2012 „Prosty sowiecki człowiek” a „człowiek radziecki”: analiza porównawcza badań rosyjskich i polskich socjologów, w: M. Głowacka-Grajper, R. Wyszyński (red.), 20 lat rzeczywistości poradzieckiej. Spojrzenie socjologiczne, Warszawa, s. 65-75.

Engelking A.

2012 Kołchoźnicy. Antropologiczne studium tożsamości wsi białoruskiej na przełomie XX i XXI wieku, Toruń.

Humphrey C.

2010 Koniec radzieckiego życia. Ekonomie życia codziennego po socjalizmie, przeł.

A. Halemba, Kęty.

Kubik J.

2012 Homo Sovieticus and Vernacular Knowledge, w: M.J. Aronoff, J. Kubik, Anthropology and Political Science, New York-Oxford, s. 240-278.

Lewada J. (red.)

1993 Sowietskij prostoj czełowiek: Opyt socyalnogo portrieta na rubieże 90-ch godow, Moskwa.

Lewada J.

2000 Homo Post-Sovieticus, „Obszcziestwiennyje nauki i sowriemiennost”, nr 6, s. $5-24$.

Malewska-Szałygin A.

2008 Wyobrażenia o państwie i władzy we wsiach nowotarskich 1999-2005, Warszawa. Mauss M.

1973 Szkic o darze. Forma i podstawa wymiany w społeczeństwach archaicznych, przeł.

K. Pomian, w: tegoż, Socjologia i antropologia, Warszawa, s. 209-415.

Obrębski J.

2007a Polesie archaiczne, w: J. Obrębski, Polesie. Studia etnosocjologiczne, t. 1, oprac.

A. Engelking, Warszawa, s. 33-185.

2007b Dzisiejsi ludzie Polesia, w: J. Obrębski, Polesie. Studia etnosocjologiczne, t. 1, oprac.

A. Engelking, Warszawa, s. 276-318.

Rakowski T.

2009 Łowcy, zbieracze, praktycy niemocy. Etnografia człowieka zdegradowanego, Gdańsk. 
Sztompka P.

2000 Trauma wielkiej zmiany. Społeczne koszta transformacji, Warszawa.

Taylor C.

1995 Źródła współczesnej tożsamości, przeł. A. Pawelec, w: K. Michalski (red.), Tożsamość w czasach zmiany. Rozmowy w Castel Gandolfo, Kraków, s. 9-21.

Thomas W.I., Znaniecki F.

1976 Chłop polski w Europie i Ameryce, t. 1, Organizacja grupy pierwotnej, przeł. M. Metelska, Warszawa.

Tischner J.

2005 Etyka solidarności oraz Homo Sovieticus, Kraków.

Zinowiew A.

1984 Homo sovieticus, przeł. S. Deja, Londyn.

1986 Homosos, przeł. S. Deja, Warszawa.

\section{Rozmówcy}

B06Kos.AL: mężczyzna, l. ok. 60, prawosławny; m. gm. Kosów, rej. iwacewicki, obw. brzeski; rozm. A. Engelking, 2006.

B99Dreb.EJ: kobieta, 1. 59, prawosławna; Drebsk, gm. Kożangródek, rej. łuniniecki, obw. brzeski; rozm. A. Engelking i O. Łobaczewska, 1999.

G97Dyl.BS: kobieta, 1. 62, katoliczka; Dylewo, gm. Wawiórka, rej. lidzki, obw. grodzieński; rozm. M. Just, 1997.

G97Mac.WR: kobieta, 1. 66, katoliczka; Maciasy, gm. Małe Możejkowo, rej. lidzki, obw. grodzieński; rozm. D. Kołakowska, 1997.

G98Bl.JWM: kobieta i mężczyzna, 1. 68 i 74, katolicy; Bieluńce, gm. Nacza, rej. woronowski, obw. grodzieński; rozm. A. Engelking, 1998.

H03Aksndr.JD: kobieta, 1. 75, prawosławna; Aleksandrowka, gm. Małe Auciuki, rej. kalinkowicki, obw. homelski; rozm. R. Kabaczij, E. Maźko, 2003.

H03Aleks.HAK: kobieta, 1. 70, prawosławna; w. gm. Aleksicze, rej. chojnicki, obw. homelski; rozm. A. Engelking, R. Kabaczij, 2003.

H03Hlin.PK: mężczyzna, 1. 76, prawosławny; Hliniszcze, gm. Aleksicze, rej. chojnicki, obw. homelski; rozm. J. Korykau, P. Koszman, 2003.

H03Jur.PP: kobieta, 1. 79, prawosławna; w. gm. Jurewicze, rej. kalinkowicki, obw. homelski; rozm. I. Alunina, O. Linkiewicz, 2003.

H03Mauc.HJ: mężczyzna, 1. 64, prawosławny; w. gm. Małe Auciuki, rej. kalinkowicki, obw. homelski; rozm. A. Engelking, S. Czuwak, 2003.

H03Mauc.MB: mężczyzna, 1. 79, prawosławny; w. gm. Małe Auciuki, rej. kalinkowicki, obw. homelski; rozm. I. Alunina, O. Linkiewicz, 2003.

H03Rom.JP: mężczyzna, l. ok. 40, prawosławny; Romanowka, gm. Słoboda, rej. mozyrski, obw. homelski; rozm. S. Czuwak, 2003. 